Users as innovators? Exploring the limitations of user driven innovation

Paul Trott, Patrick Van Der Duin and Dap Hartmann

Delft University of Technology

Faculty of Technology, Policy \& Management

Section of Technology Strategy \& Entrepreneurship

Jaffalaan 5, 2628 BX Delft, P.O. Box 5015,

2600 GA Delft, The Netherlands.

All future correspondence to:

P Trott

Email: paul.trott@port.ac.uk

Tel: +44 (0)2392 844245

Fax: $+44(0) 2392844037$ 


\title{
Users as innovators? Exploring the limitations of user driven innovation
}

\begin{abstract}
Considering users as innovators has gained considerable support over the past thirty years. Eric von Hippel's work in this area $(1976 ; 1988)$ forms a significant part of the theoretical underpinning and evidence behind this concept. Many further studies have been undertaken to support it (e.g., Urban and von Hippel, 1988; Shah, 1999). It has contributed to our understanding of innovation management in general and new product development in particular. Even so, Luthje and Herstatt, (2004) emphasise that 'empirical findings are scarce' and the most radical innovations of the last 25 years were not developed by users. Thus, in this paper we critically review the lead-user theory and focus on three specific areas of weakness of the lead-user concept (conceptual, methodological, empirical), and argue that improvement in these areas would considerably strengthen its standing. We conclude that although lead-users can contribute to the innovation process, this contribution should not be over stated and that insufficient attention has been paid to the limitations of this theory.
\end{abstract}

\section{Keywords:}

Innovation, innovation process, users, lead-users, sources of innovation, new product development. 


\section{Introduction}

The theory that users innovate has become established within the mainstream innovation management literature. It has challenged the dominance of the technology push model of innovation that had dominated science and innovation policy since the 1950s and beyond (Bush, 1945). Indeed, the extent of research exploring the role of users as innovators has been extensive (see Table 1). It covers a diverse group of academic fields adopting a variety of theoretical perspectives, including social exchange theories and economic incentives theories for information sharing. Furthermore, studies on lead user characteristics apply theoretical work from marketing and psychology, such as motivation and creativity theories, and within innovation management and technology forecasting the lead-user concept has a common currency and it is operationalised into management decision making. In view of this we hereinafter refer to this body of work as the lead-user school.

The support for the idea of users as innovators has grown over the past thirty years, however, without significant critical appraisal. This is surprising since, for instance, a quick glance at the most important innovations of the last 25 years (such as the Internet, the cell phone, and the personal computer) shows that the user involvement was quite low. In Section 3 we elaborate this issue. Recently, Schreier and Prül (2008) even argued for extending the leaduser concept beyond idea generation to more general issues in the marketing of new products. Although, Bogers et al., (2010) have recently put forward a review and critique of users as innovators, they are merely looking for theoretical holes in order to fill these and thereby strengthen the theory. We offer a wider appraisal thereby attempting to address this gap in the literature on lead users.

This paper deals with the question what are the limitations of the lead-user school. This question has arisen following our recent experiences of working with start-up firms at Technical Universities in the Netherlands. Many of these start-up firms involved advanced technology applications developed initially at the university. Our views have been informed by our observations of these start-up firms engaging with potential users and customers. We identify three key areas of weakness of users as innovators and suggest that further improvements are needed of the theory. We will argue that although lead-users can contribute to the innovation process, this contribution has been over stated and that insufficient attention has been paid to the limitations of this approach. The issues raised in this paper generate clear innovation policy implications for the firm and for government officials involved in developing innovation policies. Both need to ensure that their search for 
sources of innovation is not overly reliant on users; for curiosity driven research unfettered by the market will surely continue to provide a rich source of technological innovations.

The following section summarizes the literature on lead users. Next we present three points of criticism on the lead user school and we end this article with the implication of our criticism for how companies should deal with users as source for innovation and for governmental innovation policy.

\section{Users as innovators: an overview}

Benoit Godin has written extensively on the intellectual history of innovation. This helps us place users as innovators within the innovation literature. His work provides a detailed account of the development of the category of innovation. In his two papers "Innovation Studies: The development of a speciality I and II" (Godin, 2010a; 2010b) he explains how two traditions emerged. The first in the USA was concerned with technological change as the use of inventions in industrial production and the second in Europe which was concerned more specifically with commercialised invention. The European tradition which was developed as late as the 1970s restricted the previously broader definition of innovation as the introduction of change to a narrower focus on technology and commercialisation. Christopher Freeman is largely credited as responsible for this so called European tradition which shifted the focus of studies of innovation to the process from invention to diffusion and the consideration of policy issues specifically economic growth. The idea of a professionalised R\&D system was proposed as having a key role. According to Godin this is now the position adopted by many public organisations including the OECD. Godin argues that Freeman transformed an old meaning of technological innovation; that of introducing technical change within firms, to commercialising technological invention and so helped build a new tradition. The European tradition saw invention as part of the innovation process and introduced the function of market uncertainty. This begins to shift the focus to product development and the role of users in the testing of such products. In addition, Godin identified another rationale that Freeman put forward for wanting to include users of the technology. This was: 'Freeman believed that there is a failure in the market mechanism in relation to technical change in consumer goods and services' (Godin, 2010b:26). Godin concludes by suggesting somewhat mischievously that the two different traditions have emerged on different continents and continue to exist in almost total ignorance of each other. This helps to explain the emergence of different views on how to delineate innovation. 
In his seminal and often cited work, von Hippel was first to identify and evidence the role of users as innovators. In this study of medical equipment manufacturers in the 1970s he claimed that $80 \%$ of innovations were developed by users (von Hippel, 1976; 1977). In these papers he argued that users were the major source of innovation. Following this ground breaking work other studies have identified different types of user innovations for example: 'consumer users' and 'intermediate users'. Von Hippel (1988) argues that users in general and 'lead-users' in particular are a source of innovation and he considers the notion that companies (i.e., product manufacturers) innovate is a "basic assumption (that) is often wrong" which reflects a "manufacturer-as-innovator bias, but is nevertheless "conventional wisdom" (idem. p.117). The lead-user school sees a (predictable) distributed innovation process of which the sources vary greatly and in which users play a very important, but overlooked role. There have been several studies that provide strong evidence to support lead-users as innovators. Urban and von Hippel (1988) found that $87 \%$ of lead-users (in contrast to $1 \%$ of non-lead-users) innovated. Further evidence of innovation by lead-users is provided by Luthje (2003), who studied surgeons working at university clinics, and by Franke and von Hippel (2003), who studied webmasters using Apache's Web server software. In addition Franke et al (2006) studied kite surfers and found that those users who demonstrated high 'lead-userness' were more likely to develop commercially attractive innovations.

In their review of users as innovators in the Journal of Management Bogers, et al. (2010) explain that 'intermediate users are firms that use equipment and components from producers to produce goods and services' whereas 'consumer users-users of consumer goods - are typically individual end consumers' (Bogers et al., 2010: 859). They further illustrate that intermediate users that develop innovations have been shown to occur in the following industries: semiconductors (von Hippel, 1988), printed circuit CAD software (Urban \& von Hippel, 1988), library information systems (Morrison, Roberts, \& von Hippel, 2000). Consumer users have been found mainly in consumer products and somewhat surprisingly in sports related consumer goods such as mountain biking (Lüthje, Herstatt, \& von Hippel, 2005), and kite surfing (Tietz, Morrison, Lüthje, \& Herstatt, 2005). 
When it comes to explaining why users innovate it is argued that they possess the distinctive knowledge and expertise necessary. For example, the development of kite surfing was only possible because of the expertise gained from years of experience of windsurfing (Franke \& Shah, 2003). Indeed, in his more recent research, Von Hippel (2005) argues that when one compares innovations from producers with those of users frequently those from users are distinctive because of the unique tacit knowledge they have gained from extensive use of the products (Bogers et al., 2010).

The lead-user school further contends that while many users modify products for their own use, for example, computer hardware and software for industrial processes and high-end sports equipment, these innovations are concentrated among the "lead-users." The example of surfers is cited as an illustration, who developed an experimental surf board with footstraps that enabled them to leverage the energy of waves to make controlled flights. Leadusers, are characterised as ahead of the majority of users with respect to an important market trend, and they expect to gain relatively high benefits from the solution to the needs they have encountered: “...lead-users are users whose present strong needs will become general in a marketplace months or years in the future" (idem., p.107). Further, it is argued that by focusing on working with lead-users, companies can increase the probability that they will discover innovative solutions that they can leverage and sell to their other customers. For companies seeking to increase their capacity to innovate, the lead-user school argues that it provides a firm foundation for a strategy of innovating with selective customers; and that it is a much more effective basis for an innovation strategy than the more traditional technology centered approach, where scientific exploration and technology development lead to opportunities for firms to exploit. This approach led to the growth of a whole new sport, 'kite-surfing': "Clearly this had little to do with surfboard manufacturers who did not discover this innovation; rather it was innovative surfers“" (Franke et al., 2006).

The lead-user school recognises users (both consumers and companies) as an essential knowledge source for the innovation process. Hence, it distinguishes between ordinary users and lead-users. It argues that ordinary users have difficulties in providing fresh and relevant insights into the product development process since their familiarity with existing products "interferes with their ability to conceive of novel products and uses when invited to do so" (Von Hippel, 1988, p.103). This is rooted in their inability to come up with new solutions 
because they are not creative enough and they have difficulties in evaluating new and (thus) unfamiliar products that fall outside their real-world.

The development of commercially successful new products has consistently shown the need for accurate understanding of the needs of the user. Within the marketing literature, this is firmly established (see Deshpande', Farlley and Webster, 1993; Kohli and Jaworski, 1990). Although Von Hippel, discusses the limitations of market research in The sources of Innovation (first section of Chapter 8), it is from this premise that Von Hippel builds his arguments for the role of lead-users. According to Von Hippel lead-users are familiar with conditions that lie in the future for others, they can serve as a need-forecasting laboratory for marketing research $(1988$, p.107). Significantly it is their activities at attempting to fill their needs, which Von Hippel identifies as providing opportunities for firms wishing to develop new products. Much of the work on the users as innovators has centred on how firms should identify lead-users and how firms can incorporate their perceptions into new products. This has tended to focus on technology intensive industries and products.

Table 1 offers a summary of the widespread adoption of the lead-user concept, grouped into the themes found in the existing literature. This is not an exhaustive listing, merely an illustration of the prevalence of the lead-user school of thought within the literature. In the next section we systematically examine the concept in an attempt to illuminate our understanding of the management of innovation at the level of the firm. 
Table 1: A summary of the widespread adoption of the 'Lead-user Concept' (grouped into the themes found in existing literature)

\begin{tabular}{|l|l|}
\hline Themes & Selected representative references \\
\hline Lead-user concept development & $\begin{array}{l}\text { Franke, N., von Hippel, E., \& Schreier, M. (2006); Schreier, Martin, Prügl, } \\
\text { Reinhard (2008); Spann M, Ernst H, Skiera B, Soll JH. (2009); Baldwin et } \\
\text { al (2006); Baldwin and von Hippel (2011). }\end{array}$ \\
\hline Characteristics of lead-users & $\begin{array}{l}\text { Lüthje, C. (2004); Morrison, P.D., Roberts, J.H., Midgley, D.F. (2004); } \\
\text { Tronsden T.J., (1996); }\end{array}$ \\
\hline $\begin{array}{l}\text { Users as a source of product } \\
\text { ideas }\end{array}$ & $\begin{array}{l}\text { Lilien, G. L., Morrison, P. D., Searls, K., Sonnack, M., \& von Hippel, E. } \\
\text { (2002); Herstatt, C., \& von Hippel, E. (1992); Lilien, G., Morrison, P.D., } \\
\text { Searls, K., Sonnack, M., and von Hippel, E. (2002); Urban, Glen and Eric } \\
\text { Von Hippel (1988); }\end{array}$ \\
\hline $\begin{array}{l}\text { Management of firm innovation } \\
\text { processes }\end{array}$ & $\begin{array}{l}\text { von Hippel, E., Thomke, S., \& Sonnack, M. (1999); von Hippel, E. (1977); } \\
\text { Jeppesen, L.B., Molin, M.J. (2003); Robey, D., and Farrow, D.L. (1982, ); } \\
\text { Olson, E.L., Bakke, G. (2001); }\end{array}$ \\
\hline Innovation policy & $\begin{array}{l}\text { Riggs, W., \& von Hippel, E. (1994); von Hippel, E. (1982); Lettl, C., } \\
\text { Herstatt, C., Gemuenden, H.G. (2006); }\end{array}$ \\
\hline
\end{tabular}

\section{The role of lead users within innovation processes: three areas of criticism}

In the previous section we described how users can contribute to innovation processes and how lead-users can be a valuable source of innovation. In this section we review the leaduser school. In short, much of the evidence is based on idiosyncratic case studies and cannot be generalised. Furthermore, the lead-user school is based on an unusual definition of innovation. Empirical research on the sources and patterns of innovation make clear that users are just one of many different sources of innovation.

\subsection{Conceptual: invention is not innovation}

One major problem with the lead user school is that even though the word 'innovation' appears 1389 times in his book Sources of Innovation (1988), Von Hippel does not provide the reader with a definition of innovation. More recently Bogers and West (2012) have also argued for more clarity in terms of defining what can be considered an innovation. The majority of the user innovations that he presents appear to be merely (small) modifications to existing products. Following on from Godin (2010a; 2010b) surely most researchers would hesitate to call a modification an innovation. Of course the boundary between a modification 
and an innovation is quite vague, as is the transition of the point at which a modification becomes an innovation. Von Hippel does not seem to make that distinction. For example, in Table 3-3 (Von Hippel, 1988, p.31) he lists a sample of tractor shovel innovations in two categories: 'major improvements' and 'significant special-purpose accessories'. Adding power steering to a tractor shovel can be considered a major improvement, but is it an innovation? Von Hippel does define innovator as "the individual or firm that first develops an innovation to a useful state, as proven by documented, useful output". That is rather vague and does not get us any closer to the question what he means by innovation. Von Hippel claims that in both the process equipment industry and the electronics industry "the innovators are most often users".

In general, innovation is understood to mean much more than having an idea that could lead to the development of a new product or service (Garcia \& Calantone, 2002). Innovation encompasses the entire process of developing an idea through to a new product or service that is implemented in a market and which consists of activities such as R\&D, technology transfer, knowledge management, market research, futures research, technology intelligence, product development, and many more. In that respect, the lead-user school distinguishes four different stages in this (innovation) process: 1) identify need, 2) research/development, 3) build prototype, 4) apply commercialise and diffuse innovation; of which the user is carrying out the first three and the manufacturer only the last step (Von Hippel, 1988, p.25). The leaduser school does not explain why the first three roles are only played by users and not by manufacturers. This seems to be more an assumption than an empirically established fact. Given that the closer the innovation process is to the market, the more 'innovation resources' (finance, personnel, time) are required (Meredith \& Mantel, 2006; Turner, 1999), being the source for an idea (invention) is a relatively small component of the entire innovation process. Consequently, the lead-user school portrays lead-users as a source of ideas (which is undoubtedly true) but then overstates their role within the innovation process by underestimating the amount of 'innovation resources' (money, time, risk) other actors (i.e., not-users) spend in carrying out that part of the innovation process.

The limited role of the user in the innovation process is also clearly illustrated in the theories of 'innovation systems' (e.g., Carlsson, 2002) and 'open innovation' (Chesbrough, 2003). Both views on innovation are based on the notion that nowadays knowledge has become widely distributed and every actor involved in the innovation process should be aware that 
most of the required knowledge for innovation can be found elsewhere. Not only are there more sources of innovation (than just the user) but also that 'modern innovation' is about how these different actors are related to each other and are capable of sharing information and knowledge. So, it is not about which source of innovation can indeed be considered as such, but about how different sources of innovation together constitute the innovation process (system). Indeed, much empirical research on finding success factors for innovation show that there can be many different sources of innovation, often depending on the type of industry in which the innovation is being developed (see e.g., Miller \& Blais, 1993; Pavitt, 1983).

So, we conclude that the lead-user school's emphasis on the large or even dominant role of users in the innovation process is based on an old fashioned definition of innovation. Because of this it has understated the activities of the other actors that play such a vital role in the entire innovation process most notably the firm. As a consequence, what the lead-user school label as innovations are predominantly inventions.

\subsection{Methodological: case studies are difficult to generalize}

The lead-user school is almost entirely based on the case-study research methodology. In general, this methodology is applied when no theory is available and the researcher carries out an exploratory study to establish the first cornerstones of a theory that later-on can be tested and validated (Yin, 1994). The goal of the case-study research is not to find results that are representative and/or significantly valid for an entire population. Rather, case studies are merely meant to find a unique empirical phenomenon of which up front it is difficult to decide whether it is valid for the rest of the (not researched) population. In other words, the external validation of case studies is doubtful and difficult to establish. However, establishing external validated results is not the first priority of a case researcher since his or her first concern is not to provide such results, but to find the particular instead of the general.

Despite these limitations the lead-user school has no difficulty extending its case results to other non researched cases. And although it is possible to do so by applying analytical (or theoretical) generalization, the lead-user school does not argue why its cases are also valid in other (non-researched) industries. It does not make clear why its cases exhibit the same 
characteristics as non-researched cases. Furthermore, their cases appear quite exotic. It is difficult to understand why, for example, scientific instruments and surfboards are regarded as everyday businesses and therefore easy to apply to any other industry. We acknowledge that it is sometimes necessary to begin the exploration of a new phenomenon by studying extreme cases as a way to show the existence of it. In many ways, however, this underscores our point about it being overstated.

Strictly speaking, one can argue that the lead-user school is not really doing case studies. The case-study method attempts to discover (causal) mechanisms and processes that relate different found concepts or empirical phenomena. The case study method is mainly qualitative by nature and holds a process view on the units of analysis under investigation. In the lead-user school cases are innovations that have been developed either by users or by producers. As such, the lead-user school is merely looking at the outcomes of innovation processes and listing who was the main source of the innovation. Its main concern is not to go deep into how these innovations are being developed, but to decide which part of the innovation is developed by users and which part by producers. The descriptions of the user developed innovations is limited and does not provide an understanding of how specifically these user-centred innovations are being developed.

Furthermore, the difficulty of extending the conclusions of a few cases to other nonresearched cases also presents a methodological problem of a temporal nature. That is, the lead-users in one case (i.e., an industry at a certain time) do not necessarily have to be the future lead users in that industry. Lead users might be good predictors of future demand in that industry, but that does not imply that they will also be the right forecasters of the next generation of new products and services in that industry. For instance, because of their special relationship with a new product they might be more locked-in to that product and have many more difficulties to switch to new products than non-lead users might have since they are less (emotionally and functionally) attached to the former new product. So, for companies listening to former lead users in developing new products and services this is certainly not without any risks. And from a research perspective it means that the predictive power of case-studies should be seriously questioned.

Another methodological weakness is that the lead-user school puts lead users and companies within the same research population while they are two different empirical categories. Users 
are, in principle all the inhabitants of a certain geographical area and surely will outnumber the amount of companies which are institutional constructions. Stating that users innovate more than companies is comparing apples with oranges; especially because the role of the user and the company are so different in the innovation process: you simply cannot consider them as one research population.

\subsection{Empirical: most radical innovation are of technological origin}

When we consider some of the most significant technological developments over the past twenty years such as the World Wide Web (1990); gene therapy (1990); or the Hubble telescope (1990) it seems these were the result of scientific curiosity, unfettered by the demands of the market. So, if users are the predominant source of innovation, the list of the recently most important (radical) innovation should contain many innovations that were based on ideas developed by users. Such a list was made in 2005 in collaboration with the Lemelson-MIT Program containing the 25 most important innovations of the past 25 years. The list contains "25 non-medical innovations that have become widely used since 1980, are readily recognizable by most Americans, have had a direct and perceptible impact on everyday life and could dramatically affect the future." Table 2 shows that list (CNN 2005).

Table 2: The 25 most important innovations of the past 25 years

\begin{tabular}{|l|}
\hline 1. The Internet \\
\hline 2. Cell phone \\
\hline 3. Personal computer \\
\hline 4. Fiber optics \\
\hline 5. E-mail \\
\hline 6. Commercialized GPS \\
\hline 7. Portable computers \\
\hline 8. Memory storage discs \\
\hline 9. Consumer level digital camera \\
\hline 10. Radio frequency ID tags \\
\hline 11. MEMS \\
\hline 12. DNA fingerprinting \\
\hline 13. Air bags \\
\hline 14. ATM \\
\hline 15. Advanced batteries \\
\hline 16. Hybrid car \\
\hline 17. OLEDs \\
\hline
\end{tabular}




\begin{tabular}{|l|}
\hline 18. Display panels \\
\hline 19. HDTV \\
\hline 20. Space Shuttle \\
\hline 21. Nanotechnology \\
\hline 22. Flash memory \\
\hline 23. Voice mail \\
\hline 24. Modern hearing aids \\
\hline 25. Short range, high frequency radio \\
\hline
\end{tabular}

As with any list, the validity of the items on the list and their ranking can be criticized. For example, nanotechnology is a scientific discipline, not an innovation. The results of nanotechnology research can be innovations. Half products such as carbon nanotubes and nanoparticles may be used in consumer products ranging from golf balls to foot warmers and from skin care products to military-grade disinfectants. Even without the historical records of who or what can be attributed as the source of each innovation on the list, the items can be ranked in the likelihood that the source is an end-user, from 'absolutely inconceivable' (such as the Space Shuttle and nanotechnology) via 'highly unlikely' (Hybrid car, HDTV, cell phone) and 'unlikely' (display panels, MEMS) to 'possibly' (voicemail, modern hearing aids).

To describe the development of all the innovations on this list is too much for this article, so let us focus on the number 1: the Internet. The Internet is sometimes described as a user innovation. Certainly, the early precursors of the present Internet (such as ARPANET and NFSNET) were created by the ARPA and NSF agencies for their own use. But if that makes it a user innovation, then the Space Shuttle too is a user innovation. A name that frequently comes up in discussions about user innovations and the Internet is Tim Berners-Lee, the inventor of the World Wide Web (www). Berners-Lee is a physicist and computer scientist who developed the HyperText Markup Language (HTML), a computer implementation of hypertext, an idea first described in an article titles "As We May Think" by Vannevar Bush (1945). Berners-Lee also created the first browser to access documents written in HTML. The purpose of this software project was to create an information system through which researchers could share and update information (Berners-Lee, 1989). The World Wide Web was born when Berners-Lee joined his hypertext protocol with the Internet: "I just had to take the hypertext idea and connect it to the Transmission Control Protocol and domain name system ideas and - ta-da! - the World Wide Web.” (Berners-Lee, 2011). Surely there 
can be few who would thus conclude the World Wide Web is a user innovation? The source of the innovation can be traced back to Vannevar Bush's idea of hypertext. Another inventor that was inspired by that same article is Douglas Engelbart, inventor of the computer mouse, the word processor and the hyperlink.

We can conclude that the hypothesis that users are the source of most radical innovation is not substantiated by this list of the most important innovations from the last 25 years. Indeed, a more in-depth look at the innovations on this list shows that behind every (radical) innovation there is always a person or group of persons but these persons do not have to be users. On the contrary, these people are in most cases scientists, researchers or entrepreneurs who develop new technologies and put great effort in using these technologies as an input to new product development in the context of the organisation in which they are employed.

\section{Concluding remarks}

From the outset we would like to make clear that the lead-user school has made a significant positive contribution to our understanding of the management of innovation. Our intention here is to try to make a critical contribution. In the above sections we have attempted to explore the theory of lead-users as innovators and examine and critique it. To us it seems the lead-user theorists are making a classic hasty generalization by reaching an inductive generalization based on insufficient evidence. The lead-user theory has based a broad conclusion upon the statistics of a survey of a small group that fails to sufficiently represent the whole population. Furthermore, we argue that the lead-user school is using an outdated definition of innovation by considering inventions as innovations. Lastly, it seems not unreasonable to conclude that given that the most important or radical innovations of the last 25 year have not been developed by users indicates that the empirical basis of lead-user is limited.

From a rhetorical perspective, we think that the lead-user school uses a straw man argument with the implication that the alternative to a lead-user approach to innovation is a technology push model. This is simply misleading, for the arguments surrounding models of innovation and the need for both market and technology inputs are well known and understood (Rothwell, 1992; Berkhout et al., 2007). Furthermore, literature on ambidexterity has shown 
that combining both approaches are quite difficult to execute but can benefit a company significantly (e.g., Lee, Rho, Kim and Ju Jun, 2007; Andriopoulos and Lewis, 2010; O'Reilly and Tushman, 2004). This linkage between technology-push and market-pull should be explored more with the goal to inform companies more specifically and concretely on how best to achieve it. In this respect, we would like to draw attention to the Cyclic Innovation Model (CIM), an 'innovation system'-model that not only structures the different innovation actors involved and at the same time stresses the non-feedback nature of many innovation processes, but also puts forward that the different 'nodes' of an innovation system can function as different sources of innovation (Berkhout, Hartmann and Trott, 2010). According to the CIM, innovation processes can start either with scientific insights, new technological knowledge, different product requirements, and, last bust not least changes in market needs. The essential point of CIM is that although the innovation process starts at one of the four innovation sources, innovation processes can only be successful if these sources are being related to each other by (cyclical) knowledge flows. The innovation source, even if it is the marker need, just functions as a starting point and it is the combination of the different innovation sources (nodes) that forms the core of the innovation system.

The notion of innovation processes having different innovation sources (and more than just user needs) is also in line with the contingency approach that states that there is not just one factor (or set of factors) that explain or describe the success of innovation processes. Indeed, much empirical research on innovation comes close to stating that there is no single (successful) way of innovating, but that there are many different ways of delivering innovate products, of which user-centred innovation is just one (Pavitt, 1984; Miller and Blais, 1993; Ortt and Van der Duin, 2008). Users and 'lead-users' may sometimes be helpful, but may not always be so.

The marketing literature can assist the lead-user school in its development by considering a wide variety of roles consumers and business users can play in the new product development process (Nambissan, 2002). Indeed, within consumer product markets this type of consumer research has been undertaken for more than fifty years and has delivered a rich source of new product ideas. For instance, within technology intensive consumer product industries the role of the consumer is largely that of inactive buyer with a few informed consumers having either a symbolic involvement or being an information provider. This inactive role 
even extends to customers within the supply chain. Clearly in business-to-business product industries the role of the consumer (user) has been very different. Indeed here we find many examples of consumers involved in co-developing products. The continuum developed by Vargo and Lusch (2004) for the development of new services illustrates the degree of customer (user) involvement (see Figure 1).

Figure 1: Degree of customer (user) involvement in NPD

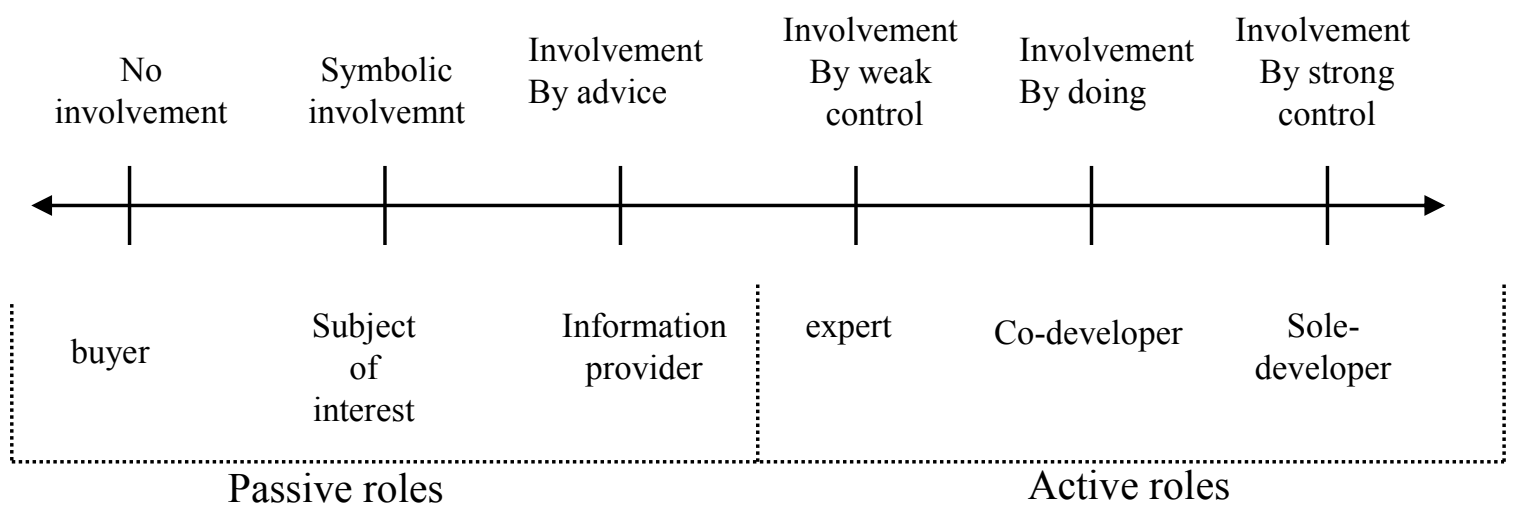

Source: Vargo and Lusch (2004).

In principle, the marketing context can provide relevant information and knowledge to ensure the development of innovative new products and the acceptance and diffusion of new products. In both cases it is usually the insights with respect to understanding potential customers that marketing supplies. Uncovering and understanding these insights is where effective marketing is valuable.

Despite the potential value of users for the innovation processes of companies, the deep insights necessary for truly innovative products requires great skill as much of the information gained from customers for such products needs to be ignored (Veryzer, 2003). Research within marketing has shown for many years that gaining valuable insight from consumers about innovative new market offerings, especially discontinuous new products, is extremely difficult and can sometimes lead to misleading information (Tauber, 1974; King, 1985; Martin, 1995; Hamel and Prahalad, 1994; Veryzer, 2003). Indeed, frequent responses from (potential) users are along the lines of "I want the same product only cheaper and better". In addition, students of innovation management may recall Clayton Christensen's book the innovator's dilemma (1997) wherein he argued that the main reason for the market 
leaders from IBM to Xerox failing was that they listened too closely (sic) to what their customers wanted rather than by looking beyond their immediate needs.

Furthermore, the benefits of discontinuous innovations to potential users may be difficult to identify and value, and usually because there are likely to be few substitute products available it is difficult for buyers to compare and contrast. Sometimes product developers have to lead buyers/consumers and show them the benefits, even educate them. This is where some marketing views suggest the process is no longer customer-led or driven by users, and they would argue that what is now occurring is a technology-push approach to product development. So, it seems there are a number of false dichotomies here (Day, 1999), such as:

- that you must either lead or follow customers;

- that you cannot stay close to both current and potential customers; and

- that technology-push cannot be balanced with market-pull.

This is compounded by higher levels of risk for both the customer and the producer. Herein lies the problem: highly innovative products have an inherent high degree of uncertainty about exactly how an emerging technology may be formulated into a usable product and what the final product application will be. Market vision or the ability to look into the future and picture products and services that will be successful is a fundamental requirement for those firms wishing to engage in innovation, but also very problematic (Van der Duin, 2006). It involves assessing one's own technological capability and present or future market needs and visioning a market offering that people will want to buy.

Our criticism on the lead-user school has two implications for governmental policy:

- The lead-users school more or less regards invention as innovation. If governments adopt this standpoint they predominantly focus their innovation policy at the early stages of the innovation process within organizations thereby neglecting the end phases of organizational innovation; the processes which often requires considerable support. Also, the implication of regarding inventions as innovations may also give a misleading view of the innovativeness of a country since in many survey instruments inventions are classified as an input to the innovation. This may lead to an overstated picture of the innovativeness of a country.

- An over emphasis on the significance of lead-user theory as a driver of innovation by policy makers risks too much emphasis being placed on incremental innovations at the cost of fundamental more radical innovations. Currently, in the Netherlands innovation 
policy is dominated by large companies and industries that are decisive about those technology areas universities and other research organizations should focus. These companies consider themselves as 'users' or clients of scientific research and are not eager to finance fundamental scientific research because the technology development remains too uncertain. Hence, a large emphasis will be placed on developing scientific knowledge for incremental innovations thereby endangering the long term innovative capacity of the Netherlands.

Further research on the role of users and lead users could focus on the following topics:

- More insight into how different types of users relate to different types of innovations. How can we develop research further than the notion that radical innovations have their source in scientific and technological developments whereas incremental innovations start from users needs?

- Exploring whether lead-users for a certain type of new product or service can also function as such for other new products and services: what is the predictive power of lead-users? Once a lead-user always a lead-user?

\section{References}

Andriopoulos, C. and M.W. Lewis, Managing innovation paradoxes: Ambidexterity lessons from leading product design companies, Longe Range Planning, 2010, vol.43, pp.104122

Baldwin, C. Y., Hienerth, C., and von Hippel, E. How user innovations become commercial products: A theoretical investigation and case study. Research Policy 35 (9): 1291-1313, 2006.

Baldwin, C. Y., and von Hippel, E. Modeling a paradigm shift: From producer innovation to user and open collaborative innovation. Organization Science 22, (6), 1399-1417, 2011.

Bangle C, The ultimate creativity machine: How BMW turns art into profit, Harvard Business Review, January, 47-55, 2001.

Beise M Lead markets, innovation differentials and growth, International Economics and Economic Policy, 1:305-328, 2005. 
Berkhout, A.J., D. Hartmann \& P. Trott (2010). Connecting technical capabilities with market needs using a cyclic innovation model, R\&D Management, vol.40, no.5, pp.474490

Berners-Lee, T., Answers for Young People, http://www.w3.org/People/Berners-Lee/Kids, 2011, (Retrieved 23 May 2011).

Berners-Lee, T., Information Management: A Proposal, http://www.w3.org/History/1989/proposal.html, 1989, (Retrieved 23 May 2011).

Bogers M, Afuah A and Bastian B Users as Innovators: A Review, Critique, and Future Research Directions, Journal of Management 2010; 36; 857, 2010.

Bogers, M., and West, J. Managing distributed innovation: Strategic utilization of open and user innovation. Creativity and Innovation Management 21 (1): 61-75, 2012.

Brown, S.L. \& K.M, Eisenhardt, Product development: Past research, present findings and future directions, Academy of Management Review, 20(2), 343-378, 1995.

Bruhn C M, J.C. Bruhn, A. Cotter, C. Garrett, M. Klenk, C. Powell, G. Stanford, Y. Steinbring, E. West Consumer Attitudes Toward Use of Probiotic Cultures, Journal of Food Science, Vol 67, 5, 1969-1972, 2002.

Bush, V, Science the endless frontier, Washington, U.S. Government Printing Office, 1945.

Bush, V., As We May Think. The Atlantic Monthly, July 1945. Reprinted in Life magazine September 10, 1945.

Buur, J., \& Matthews, B. Participatory innovation. International Journal of Innovation Management, 12: 255-273, 2008.

Carlsson B, Jacobsson S, Holmén M, Rickne A Innovation systems: analytical and methodological issues. Research Policy, Vol.31, pp.233-245, 2002.

Chesbrough, H., Open innovation: The new imperative for creating and profiting from technology, Harvard Business School Press, Boston, 2003.

Christensen, C. M., The innovator's dilemma, Harvard Business School Press, Boston, Massachusetts, 1997.

CNN, 2005, http://edition.cnn.com/2005/TECH/01/03/cnn25.top25.innovations/ (Retrieved 23 May 2011)

Cooper, R.G., New product leadership: building in the success factors, New Product Development \& Innovation Management, 1,2, 125-140, 1999.

Cooper, R.G., The invisible success factors in product innovation, Journal of Product Innovation Management, 16, 2, April 1999, 115-133, 1999. 
De Jong, J. P. J., \& von Hippel, E. Transfers of user process innovations to process equipment producers: A study of Dutch high-tech firms. Research Policy, 38: 11811191, 2009.

Deshpande', R., J.U. Farley and F.E. Webster, Corporate culture, customer orientation, and innovativeness in Japanese firms: a quadrad analysis, Journal of Marketing, 57 (January), 23-27, 1993.

Dodgson, M., D. Gann, \& A. Salter, The role of technology in the shift towards open innovation: the case of Procter \& Gamble, R\&D Management, 36, 3, 333-346, 2006.

Duin, P.A. van der, J.R. Ortt \& H. Stavleu, Mind the gap: concluding remarks to the special issue, Technological Forecasting \& Social Change, Vol.74, November 2007, 1847-1851, 2007.

Feig B Marketing Straight to the heart, AMACOM, New York, 1997.

Fortune, Steven Jobs, Apple, March 3, 2008.

Franke, N \& von Hippel E, Satisfying Heterogeneous User Needs via Innovation Toolkits: The Case of Apache Security Software, Research Policy,Vol 32, No. 7, (July), 1199$1215,2003$.

Franke, N, von Hippel E and Schreier M, Finding Commercially Attractive User Innovations: A Test of Lead-User Theory', Journal of Product Innovation Management , Vol. 23, 301-315, 2006.

Franke, N. \& F. Piller, Value Creation by Toolkits for User Innovation and Design: The Case of the Watch Market, Journal of Product Innovation Management, Vol. 21 No. 6, 401-16, 2004.

Franke, N., \& Shah, S. How communities support innovative activities: An exploration of assistance and sharing among end-users. Research Policy, 32: 157-178, 2003.

Franke, N., von Hippel, E., \& Schreier, M. Finding Commercially Attractive User Innovations: A Test of Lead-User Theory. Journal of Product Innovation Management, 23(4), 301-315, 2006.

Garcia, R. and R. Calantone, A critical look at technological innovation typology and innovativeness terminology: a literature review, The Journal of Product Innovation Management, 19, 110-132, 2002.

Godin B (2010a) "innovation Studies": the invention of a speciality (Part I), Project on the intellectual history of innovation, Montreal:INRS. 
Godin B (2010b) “innovation Studies": the invention of a speciality (Part II), Project on the intellectual history of innovation, Montreal:INRS.

Hamel, G. \& C.K. Prahalad, Competing for the future, Harvard Business Review, 72(4), 122-128, 1994.

Herstatt, C., \& von Hippel, E. From experience: Developing new product concepts via the lead-user method: A case study in a "low-tech" field. Journal of Product Innovation Management, 9(3), 213-221, 1992.

Hyysalo S User innovation and everyday practices: micro-innovation in sports industry development , R\&D Management, 39, 3: 247-258, 2009.

Jeppesen, L.B., Molin, M.J. "Consumers as Co-Developers: Learning and innovation outside the firm", Technology Analysis \& Strategic Management, 15(3): 363-84, 2003.

King, S., Has marketing failed or was it never really tried?, Journal of Marketing Management, Vol 1 No 1, 1-19, 1985.

Kohli, A. K. and B.J. Jaworski, B. J., Market orientation: the construct, research propositions, and managerial implications, Journal of Marketing, 54(April), 1-8, 1990.

Lee, K., S. Rho, S. Kim and G. Ju Jun, Creativity-innovation cycle for organisational exploration and exploitation: Lessons from Neowiz - a Korean internet company, Longe Range Planning, 2007, vol.40, pp.505-523

Lettl, C., Herstatt, C., Gemuenden, H.G. Users' contributions to radical innovation: Evidence from four cases in the field of medical equipment technology. $R \& D$ Management 36, 251-272, 2006.

Lilien, G. L., Morrison, P. D., Searls, K., Sonnack, M., \& von Hippel, E. Performance Assessment of the Lead-user Idea-Generation Process for New Product Development. Management Science, 48(8), 1042-1059, 2002.

Luthje C., Customers as co-inventors: an empirical analysis of the antecedents of customerdriven innovations in the field of medical equipment. Proceedings of the $32^{\text {nd }}$ EMAC conference, Glasgow, 2003.

Lüthje, C. Characteristics of Innovating Users in a Consumer Goods Field. An Empirical Study of Sport-related Product Consumers. Technovation 24 (9):683-95, 2004.

Lynn, G. S., J.G. Morone \& A.S. Paulson, Marketing and discontinuous innovation: the probe and learn process, California Management Review, 38, 8-37.

Martin, J., Ignore your customer, Fortune, 8 (May 1), 121-125, 1996. 
Meredith, J.R. \& S.J. Mantel jr., Project management. A managerial approach, $6^{\text {th }}$ edition, John Wiley \& Sons, Asia, 2006.

Michael L. Tushman and Lori Rosenkopf Organizational determinants of social change:Toward a sociology of social change, Research in Organisational Behavior, vol 14, 311-347, 1992.

Miller, R. \& R.A. Blais, Modes of innovation in six industrial sectors. IEEE Transactions on engineering management, Vol.40, No.3, August 1993, 264-273, 1993.

Morrison, P. D., Roberts, J. H., \& von Hippel, E. Determinants of user innovation and innovation sharing in a local market. Management Science, 46: 1513-1527, 2000.

Morrison, P.D., Roberts, J.H., Midgley, D.F. "The nature of lead users and measurement of leading edge status", Research Policy, 33(2): 351-362, 2004.

Nambisan, S., Designing virtual customer environments for new product development: Toward a theory, Academy of Management Review, Vol 27 No 3, 392-413, 2002.

Olson, E.L., Bakke, G. "Implementing the lead user method in a high technology firm: A longitudinal study of intentions versus actions", The Journal of Product Innovation Management, 18: 388-395, 2001.

O'Reilly, C.A. and M.L. Tushman, The ambidextrous organization, Harvard Business Review, April 2004, pp.74-81

Ortt, J.R. \& P.A. van der Duin, The evolution of innovation management towards contextual innovation management, European Journal of Innovation Management, Vol.11, No.4, 522-538, 2008.

Ortt, R., D. Langley \& N. Pals, Exploring the market for breakthough technologies, Technological Forecasting \& Social Change, Vol.74, Issue 9, 1788-1804, 2007.

Pavitt, K., Sectoral paterns of technical change: Towards a taxanomy and a theory, Reseach Policy, 13, 343-373, 1984.

Prahalad, C. K., \& Ramaswamy, V. The future of competition: Co-creating unique value with customers. Boston: Harvard Business School Press, 2003.

Riggs, W., \& von Hippel, E. The Impact of Scientific and Commercial Values on the Sources of Scientific Instrument Innovation. Research Policy, 23(4), 459-469, 1984.

Robey, D., and Farrow, D.L. User Involvement in Information Systems Development: A Conflict Model and Empirical Test, Management Science, 28 (1), 73-85, 1982.

Rogers, E., Diffusion of innovations, $3^{\text {rd }}$ ed. Free Press, New York, 1983.

Rogers, E.M., New product adoption and diffusion, Journal of Consumer Research, 2, 290 $301,1976$. 
Rothwell, R., Successful industrial innovation: critical factors for the 1990's, R \& D Management 22 (3), 64-84, 1992.

Ryan \& Gross, The Diffusion of Hybrid Seed Corn in Two Iowa Communities, Rural Sociology, 8, March, 15, 1943.

Schreier, M, Prügl, R., Extending lead-user theory: Antecedents and consequences of consumers' lead-userness. Journal of Product Innovation Management 25 (4): 331-346, 2008 .

Shah, S., Sources and patterns of innovation in a consumer products field: innovations in sporting equipment. MIT Sloan School of Management Working Paper No. \#410 (May), 1999.

Spann M, Ernst H, Skiera B, Soll JH. Identification of lead users for consumer products via virtual stock markets. Journal of Product Innovation Management Vol 26 No 3, 322336, 2009.

Sunday Times, February 17, 2008.

Tauber M, Predictive validity in consumer research, Journal of Advertising Research, Vol 15 No 5, 59-64, 1974.

Teresa Amabile, Dorothy Leonard, Jeffrey Rayport, and Elleen Morley, Harvard Busines Review on Breakthrough Thinking, HBS Press, Cambridge, Mass, 1999.

Thomke, S.H. Experimentation Matters: Unlocking the Potential of New Technologies for Innovation, Harvard Business School Press, Boston, 2003.

Townes, C.H. How the Laser Happened. Oxford University Press, ISBN 0-19-512268-2, 1999.

Tronsden T.J. Some characteristics of adopters of a major innovation in the computer field and of potential use in marketing. Industrial Marketing Management 25 6, pp. 567-576, 1996.

Trott P Innovation Management and new product development $5^{\text {th }}$ ed., Prentice Hall, London, 2011.

Turner, R. The handbook of project-based management, $2^{\text {nd }}$ edition, McGraw-Hill, London, 1999.

Urban, Glen and Eric Von Hippel Lead User Analyses for the Development of New Industrial Products, Management Science, 34 (5), 569-862, 1988.

Vargo, S. L. and Lusch, R. F., Evolving a new dominant logic for marketing, Journal of Marketing, 68 (1), 1-17, 2004. 
Veryzer, R. Marketing and the development of innovative products, in Shavinina, L. (Ed.), International Handbook on Innovation, Pergamon Press, Canada, pp. 6-17, 2003.

von Hippel, E. Appropriability of innovation benefit as a predictor of the source of innovation. Research Policy, 11(2), 95-115, 1982.

Von Hippel, E. Democratizing Innovation, MIT Press, Cambridge, Massachusetts, 2005.

von Hippel, E. Transferring process equipment innovations from user-innovators to equipment manufacturing firms. $R \& D$ Management, 8(1), 13-22, 1997.

Von Hippel, E., Lead-users: A source of novel product theorys, Management Science, July, 32(7), 791-805, 1986.

Von Hippel, E., Perspective: User Toolkits for innovation, Journal of Product Innovation Management, 18(4), 247-257, 2001.

Von Hippel, E., The sources of innovation, Oxford University Press, New York/Oxford, 1988.

von Hippel, E., Thomke, S., \& Sonnack, M. (1999). Creating Breakthroughs at 3M. Harvard Business Review, 77(5), 47-57.

Wayland, R. \& P. Cole, Customer Connections, Harvard Business School Press, Boston, 1997.

Yin, R., Case study research. Design and methods, SAGE Publications, London, 1994. 
Page 25 